\title{
MOTIVASI TINDAKAN SALMAN FARIS DALAM MEMBANGUN DISKURSUS KARISMA TUAN GURU DALAM NOVEL TUAN GURU
}

\author{
Faozan \\ Universitas Sebelas Maret \\ ojanfao@gmail.com
}

\begin{abstract}
This article aims to reveal the motivation behind Salman Faris' action in building the discourse of Tuan Guru charisma in the Tuan Gurunovel. Data in this research are all expressions of language and utterancesconstituting the discourse of Tuan Guru charisma in the Tuan Guru novel and data obtained through interviews with the most representative informants. Data were analyzed using the theory of discourse developed by Foucault used electrically with Baudrillard's simulacra theory. The analysis showed that Salman Faris builtthe discourseof Tuan Guru charisma based on observation and social interaction with the people of Lombok in the central neighborhood of Tuan Guru, so Salman Faris successfully uncovered the motivation of action of Tuan Guru in Lombok people who have a goal to be the ruler. Tuan Guru is the most influential religious figure in Lombok.
\end{abstract}

Keywords: Salman Faris, the discourse of Tuan Guru Charisma, the Tuan Guru novel

\begin{abstract}
ABSTRAK
Artikel ini bertujuan untuk membongkar motivasi tindakan Salman Faris dalam membangun diskursus karisma Tuan Guru di dalam novel Tuan Guru. Data yang digunakan dalam penelitian adalah semua ekspresi bahasa maupun ungkapan-ungkapan yang merupakan diskursus karisma Tuan Guru yang terdapat dalam novel Tuan Guru serta data yang didapatkan melalui hasil wawancara dengan para informan yang dianggap paling representatif. Data yang ada dianalisis dengan teori diskursus oleh Foucault yang digunakan secara eklektik dengan teori simulacra Baudrillard. Hasil analisis menunjukkan bahwa Salman Faris membangun diskursus karisma Tuan Guru atas dasar pengamatan dan interaksi sosial dengan masyarakat Lombok di tengah lingkungan Tuan Guru maupun di luar, sehingga Salman Faris berhasil membongkar motivasi tindakan Tuan Guru di tengah masyarakat Lombok yang memiliki tujuan untuk menjadi penguasa. Tuan Guru merupakan tokoh agama yang paling berpengaruh di Lombok.
\end{abstract}

Kata kunci: Salman Faris, diskursus karisma tuan guru, novel tuan guru 


\section{PENGANTAR}

Karismatik Tuan Guru lahir dari beberapa penilaian masyarakat yang dianggap sebagai syarat yang wajib ada dalam diri Tuan guru, sehingga Tuan guru dianggap berkarismatik sudah memiliki kriteria yang harus ada seperti; saleh, haji, pernah menuntut ilmu ke Mekah atau Kairo, memiliki pengetahuan agama luar, dan faktor legitimasi. Syarat tersebut merupakan mutlak yang ada harus ada dalam diri Tuan Guru, karena itu merupakan indikator dari karismatik dalam diri Tuan Guru.

Realitas inilah yang kemudian dieksplorasi oleh Salman Faris dalam bentuk fiksi. Melihat ketimpangan yang dianggap benar oleh masyarakat menjadi satu kejelian Salman Faris sebagai pengarang dalam melihat fenomena yang sudah mengakar pada masyarakat Lombok. Karisma yang ada dalam diri Tuan Guru menjadi pengaruh serius membentuk kepatuhan masyarakat Lombok, sehingga Salman Faris berani membongkar ketimpangan tersebut dengan membangun diskursus baru yaitu menulis novel Tuan Guru.

Pada umumnya, diskursus itu dikaitkan dengan konsep linguistik, tapi Foucault memberi arti yang berbeda. Diskursus merupakan kelompok pernyataan yang menyediakan bahasa untuk membicarakan atau persentasekan suatu pengetahuan akan topik tertentu pada periode waktu tertentu (Hall, 1997:44). Diskursus merupakan produksi pengetahuan melalui bahasa dengan memberikan makna kepada subyek material dan praktik sosial. Meskipun objek material dan praktik sosial ada di luar bahasa, mereka diberi makna atau ditampilkan oleh bahasa dan kemudian dibentuk secara diskursif. Diskursus mengonstruksi, mendefinisikan, dan menghasilkan objek pengetahuan dengan cara-cara yang masuk akal sambil mengesampingkan bentuk penalaran lain sebagai cara yang tidak masuk akal (Barker, 2013:83). Dengan kata lain, diskursus adalah tenteng produksi pengetahuan melalui bahasa pada periode waktu tertentu. Produksi pengetahuan ini selanjutnya juga dikenal sebagai pembentukan wacana. Pembentukan wacana secara lebih khusus adalah pola-pola peristiwa diskursif yang mengacu, atau melahirkan suatu obyek umum pada berbagai arena (Barker, 2013:83).

Melalui kuasa pengetahuannya Salman Faris membangun diskursus karisma Tuan Guru yang ditulis berupa novel yang berjudul Tuan Guru. Novel Tuan Guru karya Salman Faris hadir sebagai representasi dari kompleksitas akan diskursus karisma Tuan Guru yang tampaknya memanfaatkan kelebihan pengetahuannya agama, sehingga membentuk masyarakat Lombok memuja dan mengagungkan ketokohan Tuan Guru.

Penelitian tentang Tuan Guru sudah banyak dilakukan. Syahrizal Akbar, et.al. (2013) melakukan penelitian tentang novel Tuan Guru. Penelitian 
ini mengungkap ketergantungan masyarakat terhadap Tuan Guru dan nilai-nilai pendidikan di dalam novel Tuan Guru. Sementara itu, Fahrurrozi (20I0) membongkar antara idealitas normatif dengan realitas sosial Tuan Guru di Lombok. Kedua penelitian diatas menunjukkan bahwa, eksistensi dan peranan Tuan Guru ditengah masyarakat Lombok sangat sentral. Artikel ini berangkat dari konsep Foucault tentang kuasa pengetahuan. Dengan demikian, penelitian ini membongkar diskursus karisma Tuan Guru yang dibangun Salman Faris di dalam novel Tuan Guru. Melalui diskursus yang ada terungkap motivasi tindakan Salman Faris dalam membangun diskursus karisma Tuan guru di dalam novel Tuan Guru. Penelitian ini akan menggunakan data kualitatif.

Penelitian ini bertujuan membongkar dan mengkritisi motivasi tindakan Salman Faris dalam membangun diskursus karisma Tuan Guru di dalam novel Tuan Guru. Sementara itu, artikel ini diharapkan dapat bermanfaat bagi masyarakat secara umum dalam memahami orang yang memiliki ilmu pengetahuan yang luas, salah satunya dalam wujud wacana. Dengan demikian, masyarakat semakin peka terhadap masalah yang selalu ada di sekitarnya. Teori diskursus dan teori simulacra digunakan bersama untuk menganalisis motivasi tindakan Salman Faris dalam membangun diskursus karisma Tuan Guru di dalam novel Tuan Guru.

\section{TEORI DAN METODE PENELITIAN}

Menurut Donald (dalam Sardiman, 2014:73), motivasi merupakan perubahan energi dalam diri seseorang yang ditandai dengan munculnya "feeling" dan didahului dengan tanggapan terhadap adanya tujuan. Salman Faris melihat fenomena dalam berpikir Tuan Guru yang dianggap menyimpang, sebagai suatu perubahan energi dalam diri seseorang ataupun kelompok, sehingga Tuan Guru menurut Salma Faris memiliki motivasi tindakan yang lain di balik pengetahuan agama yang dimilikinya. Salman Faris mengklaim, masyarakat hanya sebagai "abdi surge" bukan sebagai hamba Tuhan, karena masyarakat dijanjikan bayang-bayang keindahan surge. Hal ini terlihat dari motivasi Tuan Guru untuk mengajak masyarakat Lombok untuk berlomba-lomba melakukan amal jariah yang di dalamnya ada unsur politik Tuan Guru.

Politik Tuan Guru di sini terlihat dari setiap fatwa yang titahkan untuk dijalani oleh masyarakat dengan mengajak dalam membangun pondok pesantren bersama. Semua pondok pesantren yang ada di Lombok dikelola oleh Tuan Guru. Peran dan eksistensi Tuan Guru membentuk konstruksi berpikir masyarakat Lombok menjadi masyarakatyangmemilikisatupegangan ideologi. Taat dalam menjalankan ibadah, terbentuknya norma-norma yang berlandasan agama. Hal ini merupakan salah satu keberhasilan 
Tuan Guru dalam membentuk ideologi, sehingga masyarakat Lombok menjadi masyarakat yang taat dalam menjalankan perintah agama.

Cavallaro (2001) menjelaskan, ideologi adalah satu seperangkat praktik budaya, diskursus, kepercayaan, dan ritual yang bertujuan membentuk setiap individu dan seluruh komunitas pada dasar pandangan dunia dominan. Hal ini menginstruksikan untuk menginterpretasikan dunia dengan cara tertentu. Ideologi secara bersamaan juga mengonstruksikan subjektivitas, identitas sosial sebagai komponen struktur yang saling berhubungan antara kekuasaan dan pengetahuan.

Keberhasilan Tuan Guru membentuk masyarakat Lombok menjadi taat dalam beragama tidak lain karena pengaruh pengetahuan agama yang dimiliki Tuan Guru. Pengetahuan agama itu pula yang merupakan usur karismatik yang ada dalam diri Tuan Guru. Salamah (2015:42) menjelaskan bahwa karisma merupakan kekuasaan yang dimiliki oleh orang tertentu. Sebab, karisma tersebut dapat melahirkan panggilan bagi pengikutnya. Mereka yang terpanggil mengakui kualitas dan ketokohan arang yang berkarismatik tersebut.

Penelitian ini merupakan penelitian kualitatif deskriptif dengan pendekatan hermeneutika. Data yang digunakan dalam penelitian ini adalah data kualitatif yang bersumber dari novel Tuan Guru dan hasil wawancara informan. Data utama dalam penelitian ini adalah ekspresi-ekspresi bahasa terkait diskursus karisma Tuan Guru, seperti dialog ataupun ungkapan dalam novel serta hasil wawancara dengan informan, kemudian dianalisis guna melihat diskursus yang dibangun Salma Faris.

Artikel ini fokus pada diskursus karisma Tuan Guru yang dibangun Salman Faris, konteks sosial masyarakat yang menjadi latar belakang novel ini juga perlu disampaikan guna memahami konteks masyarakat yang melatarbelakangi novel ini. Oleh karenanya, data pendukung dalam penelitian ini berupa dokumendokumen terkait diskursus karisma Tuan Guru. Data-data yang ada kemudian dianalisis secara kritis dengan menggunakan teori-teori kritis. Salah satnya adalah teori diskursus Focault dan teori simulacra Baudrillard.

\section{HASIL DAN PEMBAHASAN}

Novel yang berjudul Tuan Guru ini berkisah tentang seorang tokoh agama yang memiliki pengaruh besar di Lombok. Dia memiliki pengetahuan agama yang luas menjadi magnet tersendiri bagi orang tersebut, yaitu Tuan Guru. Salman Faris sebagai pengarang membongkar ketimpangan yang dianggap wajar oleh masyarakat karena Salman Faris menganggap masyarakat sudah menjadi budak rohani Tuan guru yang mereka percaya sebagai panutan hidup. Dengan janji balasan akhirat, hal ini menjadi kunci keberhasilan Tuan guru menjadi 
penguasa di tengah masyarakat Lombok, terlebih lagi karena citranya yang sangat mengesankan di hati masyarakat.

Konstruksi berpikir masyarakat yang sudah termakan oleh diskursus karisma yang ada dalam diri Tuan Guru menjadi ketimpangan yang serius. Sebab, karisma ini yang membentuk masyarakat menjadi tunduk dan patuh. Seluruh masyarakat Lombok menganggap Tuan Guru sebagai tokoh yang sewajarnya, yang harus mereka ikuti dan aplikasikan setiap fatwa yang dititahkan. Akibatnya, Tuan Guru dengan mudahnya membangun diskursus disela-sela dia berbicara di tengah masyarakat.

Melihat terjadinya praktik diskursif tersebut membuat Salman Faris berani membangun membongkar karisma Tuan Guru yang merupakan dalang dari terbentuknya kepatuhan masyarakat Lombok. Berbekal pengetahuan dan hasil pengamatan ketika berinteraksi dengan masyarakat dan Tuan Guru, Salman Faris menjelaskan alur siklus Tuan Guru di dalam cerita novel Tuan Guru sebagai berikut.

\section{Dari Tokoh Masyarakat Menjadi Wakil Tuhan di Muka Bumi}

Siklus sosial Tuan Guru tidak banyak rintangan dan hambatan karena proses perjalanan hidup Tuan Guru dari masyarakat biasa menjadi orang yang dihormati tidak memiliki kendala yang serius. Mekah dan Kairo menjadi tiket utama seorang Tuan Guru untuk membentuk identitas sosial mereka di tengah masyarakat Lombok. Identitas yang menjadikan Tuan Guru selalu dipuja-puja oleh banyak orang. Hal ini akibat dari pengaruh ilmu yang dia miliki. Tuan Guru di sini, sebelum pergi ke Mekah atau Kairo dengan tujuan menuntut Ilmu, sudah memahami sistem berpikir dan sosial masyarakat Lombok. Akibatnya, dia berani ke luar negeri untuk menuntut ilmu dengan tujuan sepulangnya terpilih menjadi Tuan Guru. Terlebih lagi, tempat Tuan Guru menimba ilmu ini adalah Mekah dan Kairo, yang merupakan kota bagian dari negara Islam yang berpengaruh dalam konstruksi berpikir masyarakat Lombok. Diskursus inilah yang lahir dari konstruksi berpikir masyarakat Lombok. Sebab, Arab dan Mesir merupakan negara yang memiliki sejarah Islam yang kental dengan perjalanan para nabi. Sejarah ini dipercaya masyarakat. Bagi siapa pun yang menuntut ilmu ke Mekah atau Kairo, orang tersebut memiliki pengetahuan agama yang luas.

Konstruksi berpikir yang terbentuk dari sejarah tersebut menjadikan Tuan Guru disegani dan dipuja setelah sepulang dari Mekah dan Kairo. Lahirlah pusat kebenaran. Kebenaran tunggal yang berlandasan agama yang membentuk keyakinan masyarakat bahwa Tuan Guru tempat pengaduan dan meminta segala sesuatu yang berkaitan dengan agama, sehingga tanpa sadar masyarakat tidak lagi menganalisis terlalu dalam motivasi tindakan Tuan Guru. Hal ini diakibatkan dri kekaguman 
dalam tiap-tiap individual.

Untuk menyumbang ke pengajian tuan guru. Apa yang tidak mungkin? toh, kita akan mendapatkan balasan yang setimpal dari Allah Subhanahu Wata'ala. Terlebih kita mendapat doa dari tuan guru(TG:57).

Kutipan tersebut merupakan konstruksi masyarakat terhadap orang yang mereka yakini sebagai penolong mereka di dunia yaitu Tuan Guru. Masyarakat tidak lagi berpikir maksud dan tujuan, seperti kenapa mereka harus menyumbang di setiap pengajian. Hal ini disebabkan atas keyakinan terhadap doa seorang alim ulama akan cepat dikabulkan oleh Allah SWT.

Hai ini terjadi dalam realitas masyarakat Lombok. Pengaruh Tuan Guru sepulang dari Mekah menjadi sorotan Salman Faris sebagai pengarang novel. Tuan Guru yang baru pulang dari Mekah menjadi idola baru bagi masyarakat. Hal ini terlihat dari sikap masyarakat ketika dalam satu desa demi mendatangkan Tuan Guru untuk mengisi pengajian di masjid. Masyarakat rela menyumbang uang yang dianggap amal jariah, yang pada faktanya hanya ingin mengejar didoakan oleh Tuan Guru.

Sebuah realitas tercermin dari diskursus yang dibangun oleh Salman Faris tentang kondisi masyarakat Lombok. Hal ini terlihat dari mereka yang mengharapkan untuk didoakan oleh Tuan Guru. Hegemoni pengetahuan
Tuan Guru membentuk masyarakat berlomba-lomba untuk mendapatkan doa Tuan Guru walaupun mereka harus bayar.

Kepatuhan dalam hal ini menjadi sorotan Salman Faris karena kepatuhan masyarakat Lombok ini membentuknya menjadi masyarakat yang selalu menggantungkan hidup mereka ke Tuan Guru. Doktrin untuk selalu beribadah dikritisi Salman Faris terhadap Tuan Guru. Sebab, Salman Faris menganggap Tuan Guru lebih mengutamakan jamaahnya untuk berlomba-lomba beribadah, memperbanyak pahala agar mereka bisa masuk surga, tetapi urusan dunia tidak pernah diajarkan oleh Tuan Guru. Sebagai konsekuensinya, masyarakat tidak bisa mengubah nasib hidup mereka dari yang miskin menjadi ke kaya karena doktrin Tuan Guru yang membentuk masyarakat untuk selalu taat dalam ibadah.

Kondisi masyarakat yang seperti ini yang menjadi motivasi tindakan Tuan Guru untukterus membangun diskursus. Kekuasaan merupakan tujuan akhir dari rentetan proses yang eksistensi dan peran Tuan Guru di tengah masyarakat Lombok sehingga kepopulerannya menjadi jalan untuk mencapai tujuan yang dia diinginkan, yakni kekuasaan. Sejalan dengan konsep Foucault tentangbio-power, hal ini merupakan satu bentuk kekuasaan yang berfokus pada bagaimana mengatur kehidupan manusia pada tingkat populasi masa. Pada bio-power,institusi melakukan yang disebut "power/knoledge", dengan 
melakukan pelatihan dan pendidikan bagi individu. Hal ini meningkatkan dan mengatur kehidupan manusia secara umum (Foucault dalam Lubis, 2014:80).

Selain itu, seperti yang diungkapkan oleh Marzuki (wawancara, Januari 2016) bahwa perintah salat dan menjalankan amalan sunah yang ditekankan oleh Tuan Guru. Marzuki menganggap ajaran Tuan Guru harus diikuti karena Tuan Guru memiliki pengetahuan agama yang luas yang membuatnya untuk harus percaya setiap fatwa yang Tuan Guru sampaikan. Sebagai akibatnya, konstruksi masyarakat terhadap Tuan Guru adalah tokoh teladan karena pengaruh karismatik yang dimiliki.

Ungkapan Marzuki (2016) tersebut menjadi salah satu potret konstruksi berpikir masyarakat Lombok. Tuan Guru mengajarkan masyarakat di setiap pengajiannya hanya untuk menjalankan ibadah yang wajib dan sunah. Hal itu sejalan dengan konstruksi berpikir Salman Faris yang menganggap Tuan Guru tidak pernah membangun manusianya. Tuan Guru lebih berfokus pada membangun ibadah jamaahnya agar menjadi masyarakat yang bisa menjalankan hidup sesuai syariat agama.

Kontradiksi antara pemahaman Salman Faris dengan Tuan Guru memperjelas maksud dan tujuan Tuan Guru dan Salman Faris. Tuan Guru menekankan jamaahnya menjadi jamaah yang taat beragama sedangkan Salman Faris lebih menekankan agar Tuan Guru tidak hanya mengajarkan jamaahnya tentang agama, tetapi juga mengajarkan cara bersaing dalam menjalankan hidup, agar mereka bisa bersaing di dunia.

Keinginan Tuan Guru untuk melihat jamaahnya untuk selalu beribadah, sejalan dengan ungkapan Foucault yang mengatakan bahwa kekuasaan bukan hubungan subjektif searah. Namun, kekuasaan adalah kemampuan seseorang atau kelompok untuk memaksakan kehendak kepada orang lain. Kekuasaan merupakan strategi kompleks dalam suatu masyarakat dengan perlengkapan manuver, teknik, dan mekanisme tertentu (Foucault dalam Suryawan, 2010:118).

Power bersifat arbriter bagi pemiliknya karena di dalam power ada terlibat hasrat yang mendominasi. Hal ini melahirkan keinginan-keinginan yang membuatnya tidak pernah selesai dan puas, kekuatan untuk menguasai orang lain membentuk lingkaran politik yang membuat orang yang dikuasai tunduk (Aziz, 2001:15-16).

Power yang ada dalam diri Tuan Guru tidak lepas dari hasrat untuk menguasai. Power bersifat arbriter, yang membentuk keinginan-keinginan baru. Hal ini adalah simulasi yang muncul dari Tuan Guru.Segala motivasi tindakan Tuan Guru berlandaskan hasrat untuk menguasai hanya simulasi. Hasrat yang menguasai membentuk keinginan-keinginan yang membuatnya menjadi ingin penguasa. 
Realitas sosial ini tidak bisa terlihat oleh masyarakat.Bahkan, Tuan Guru tidak mengetahui tindakan yang dia lakukan telah memproduksi hasrat yang di dalamnya yang membentuk keinginan-keinginan baru untuk berkuasa. Masyarakat "hanyut" dalam kemampuan dan kecerdasan yang ada dalam Tuan Guru. Perlakuan masyarakat yang berlebihan terhadap dirinya menjadi motivasi tindakan Tuan Guru untuk terus membangun diskursus sampai terpenuhinya keinginan Tuan Guru. Hal ini terlihat dari kutipan di bawah.

Histeris orang tuannya Kemuk setelah anaknya berubah nama menjadi Abdul Gani bin Rizkon oleh tuan guru. Kemuk. Temanku yang cacat kakinya itu pun menangis saat itu. Seolah ia mengamini (TG:456).

Kutipan tersebut merupakan dampak dikursus yang dibangun oleh Tuan Guru. Perlakuan masyarakat terhadap Tuan Guru seperti orang yang tidak bisa berbuat apa-apa. Dia bergantung untuk mendapatkan kebaikan di dunia dengan cara berlindung dibalik pengetahuan agama yang dimiliki Tuan Guru.

Hal ini yang dimunculkan oleh Salman Faris dalam novel Tuan Guru ini, yakni bagaimana perlakuan masyarakat terhadap Tuan Guru terlalu berlebihan. Sebagai akibatnya, hal ini membentuk masyarakat menjadi tunduk terhadap kuasa pengetahuan
Tuan Guru. Pada realitasnya, tunduk dan patuh merupakan suatu sikap yang ditunjukkan oleh masyarakat Lombok terhadap Tuan Guru. Sikap tersebut menjadikan Tuan Guru seperti manusia tanpa dosa, manusia suci yang paling dekat dengan Tuhan yang sengaja diturunkan untuk masyarakat Lombok.

\section{Dari Tokoh Agama Menjadi Pusat Kebenaran}

Gelar tuan guru menjadi modal bagi seorang Tuan Guru untuk motivasi tindakannya untuk membangun diskursus di tengah masyarakat Lombok. Konvensi masyarakat membentuk seorang Tuan Guru atas dasar keilmuan orang tersebut. Awal mula lahirnya kepatuhan-kepatuhan dengan mempercayai keilmuan yang ada dalam Tuan Guru adalah munculnya diskursus Mekah yang membentuk konstruksi pemahaman masyarakat yang membentuk keyakinan. Bagi siapa pun yang ke Mekah dengan tujuan menuntut ilmu, orang tersebut dipercaya memiliki pengetahuan agama yang luas. Melalui keyakinan tersebut, masyarakat memberi gelar kehormatan kepada orang tersebut, Tuan Guru. Seperti yang di ungkapkan oleh Foucault dalam Lubis (2014:84), Tuan Guru sudah masuk dalam praktik diskursif. Jalinan, hubungan antara bahasa, pikiran, pengetahuan dan tindakan dilakukan Tuan Guru pada masyarakat Lombok. Ricour dalam Fashri (2014:34-35)mengatakan bahwa wacana dipahami sebagai peristiwa 
mengasumsikan "ada sesuatu yang terjadi ketika seseorang berbicara". Artinya, "sesuatu yang terjadi" mengacu pada pemahaman bahwa wacana adalah peristiwa dengan empat ciri yang menyertainya. Keempat tersebut antara lain adalah (1) wacana selalu terkait tempat waktu tertentu dan (2) wacana memiliki subjek dalam arti "siapa yang berbicara?" (who speaks). Peristiwa terjadi ketika ada seseorang yang menghadirkan bahasa dalam waktu dan tempat tertentu. Selain itu, yang ketiga, wacana selalu menunjuk pada sesuatu yang dibicarakan. Yang keempat (4), wacana menunjuk pada dunia yang sedang dia gambarkan, yakni wacana merupakan fokus bagi terjadinya proses komunikasi, pertukaran pesanpesan, dan peristiwa. Hal ini dilakukan oleh Tuan Guru. Kekuasaan yangd ia miliki dihadapan jemahnya membuat dirinya leluasa dalam membangun wacana di setiap pengajian yang dia pimpin. Akibatnya, fatwa-fatwa yang di keluarkan Tuan Guru selalu menjadi kebenaran bagi jamaahnya. Seperti kutipan di bawah ini:

Bapak-bapak, ibu-ibu tahu, apa sangsinya bagi warga masyarakat yang tidak menyekolahkan anaknya di madrasah? :Tahu (TG:98).

Diskursus tersebut merupakan konstruksi pemikiran Salman Faris yang melihat sikap Tuan Guru yang membuat kebenaran-kebenaran yang disampaikan di depan jamaahnya. Fatwa yang tidak akan dipertanyakan tingkat kebenarannya dalam pikiran mereka, karena kebenaran yang berlandasan agama masyarakat tidak akan pernah mempertanyakan kembali, terlebih lagi orang yang mereka percaya merupakan orang yang memiliki pengetahuan luas tentang agama, yaitu Tuan Guru.

Memahami karakter masyarakat dan ikut terlibat dalam interaksi sosial masyarakat Lombok menjadi acuan dalam diskursus Tuan Guru yang dibangun Salman Faris. Sebab, hal itu diketahui bahwa Salman Faris pernah menjadi santri Tuan Guru. Sebagai akibatnya, dia tahu cara Tuan Guru membangun diskursus di tengah masyarakat. Kemudian, dia menjadi salah satu korban diskursus tersebut.

Fatwa Tuan Guru merupakan produksi pengetahuan yang dia miliki. Hal itu membentuk kuasa yang melahirkan kebenaran baru dari Tuan Guru itu sendiri. Kebenaran sesuai norma agama menjadi acuan Tuan Guru untuk berani berfatwa di hadapan jamaahnya. Masyarakat tidak berani menentang setiap fatwa Tuan Guru, karena mereka percaya setiap fatwa Tuan Guru merupakan hasil final yang mereka harus ikuti.

Dalam praktik budaya, bukankah masyarakat mempunyai konstruksi sendiri dalam menjalankannyakarena hal itu tidak mungkin dalam suatu masyarakat berani melakukan yang dianggap melanggar norma. Sebab, praktik tersebut tidak memiliki makna. Dari sinilah, peran Tuan Guru 
memberikan pemahaman terhadap jamaahnya agar bisa mengerti dan paham dan bukan dengan cara menghapus praktik budaya tersebut. Karena budaya lahir dari hasil konstruksi pemikiran masyarakat, budaya diterima oleh masyarakat banyak. Sejalan sebagaimana pendapat Foucault(Lubis, 2014:76) bahwa dia mengemukakan adanya relasi yang signifikan antara kuasa-pengetahuankebenaran. Kuasa didapat dari pengetahuan dan dipraktikkan. Kuasa menggunakan wacana melalui bahasa. Dalam wacana itu, kebenaran dikonstruksi. Pada akhirnya, kebenaran adalah kekuasaan itu sendiri. Artinya, kebenaran pemahaman dalam praktik budaya tersebut menempati pada posisi ketidakstabilan makna. Sebagaimana pendapat Derrida (dalam Al-Fayyadl, 2005:82), makna dialami sebagai proses penafsiran dan bukan hasil yang sudah jadi. Makna ada di balik layar, tetapi wujudnya bukan dalam bentuk kehadiran. Wujudnya adalah sebagai proses-menjadi yang terusmenerus dan menunda pengertian yang dirasakan memadai. Selain itu, kuasa menggantinya dengan penandapenanda baru yang lebih terbuka dan ambigu.

Dari diskursus yang dibangun di dalam cerita novel, Salman Faris selaku pengarang ingin memunculkan perbedaan cara pandang antara Tuan Guru dengan masyarakat dalam menafsirkan suatu kebenaran. Akan tetapi, masyarakat yang sudah terhegemoni membentuknya mengikuti kebenaran yang Tuan Guru bangun. Hal itu dikemukan seperti kutipan di bawah ini.

Betapa meruginya mereka, para orang tua, yang membiarkan anak-anaknya menuntut ilmu yang lain selain ilmu agama. Anak itu akan membawakan mesinmesin dan komputer jika anak itu disekolahkan di luar sekolah agama(TG:308).

Kutipan tersebut merupakan cara Tuan Guru dalam membangun diskursus dengan mendoktrin jamaahnya. Mereka dibuat takut untuk menyekolahkan anak-anak mereka ke sekolah umum. Tuan Guru melakukan ini dengan tujuan jamaahnya menyekolahkan anak-anak mereka di pondok pesantren yang dia miliki. Realitas yang tersembunyi ini dibangun Tuan Guru dengan cara membentuk jamaahnya agar patuh dan tunduk.

Sejalan dengan pendapat Aziz (2001:20-21) mengatakan bahwa bujukan adalah yang memisahkan kebenaran dari arti dalam percakapan. Psikoanalisis Lacanian mengatakan bahwa "menandai kematian psikoanalisis, sama pastinya dengan trivialisasi institusiaonalnya". Bujukan selalu membujuk untuk mengenalkan bujukan; dia"selalu merupakan akhirnya sendiri". Membujuk adalah melemahkan. Membujuk adalah membimbangkan. Segalanya merupakan bujukan dan tidak lain merupakan bujukan. Bujukan 
yang dilakukan oleh Tuan Guru kepada jamaahnya merupakan simulasi. Sebab, simulasi merupakan kegembiraan yang sedang dalam proses. Tuan Guru membujuk jamaahnya untuk tidak sekolah ke sekolah umum. Hal ini merupakan simulasi yang berupa bujukan yang keliru. Sebab, masyarakat sudah patuh terhadap Tuan Guru. Mereka tidak berani membantah fatwa yang disampaikan Tuan Guru. Kemunculan simulasi melalui motivasi tindakan Tuan Guru memperlihatkan hasrat untuk berkuasa.

Representasi Salman Faris mengangkat ke permukaan melalui fiksi yang dia tulis ini merupakan sebuah entitas dari masyarakat Lombok pada umumnya. Salman Faris mempunyai alasan kuat untuk membongkar ketimpangan ini. Sebab, dalam biografinya, Salman Faris merupakan orang yang pernah belajar di pondok pesantren Tuan Guru. Jadi, ada banyak alasan Salman Faris berani menulis novel ini. Sebab, ada banyak pro dan kontra antara pembaca yang satu dengan yang lain, terlebih lagi Lombok merupakan basis Tuan Guru. Salman Faris juga pernah mengatakan bahwa dia sempat mau dibunuh gara-gara novel Tuan Guru ini (wawancara penulis dengan Salman Faris, Desember, 2013).Membongkar sisi lain dari Tuan Guru yang membuat novel Tuan Guru menjadi kontroversi. Sebab, hal itu diketahui bahwa Tuan Guru merupakan tokoh agama yang sangat dihormati dan disegani di Lombok. Hal ini menjadi tidak wajar ketika Salman Faris mengungkap sisi lain dari Tuan Guru yang tidak pernah terkonstruksi dalam nalar masyarakat Lombok. Akibatnya, ada banyak pro dan kontra yang membaca novel tersebut.

Interaksi dan menjalani kehidupan bermasyarakat membentuk Salman Faris beranimenulis novel Tuan Guru. Hal itu terlihat dari novel tersebut. Salman Faris membongkar politik pengetahuan Tuan Guru yang dianggap benar oleh masyarakat. Sebaliknya, Salman Faris juga mengangkat ke permukaan melalui tulisan ini tentang cara masyarakat Lombok memperlakukan Tuan Guru. Sebagai akibatnya, novel Tuan Guru ini menjadi menarik untuk dibaca. Sebab, isi novel ini mencerminkan entitas sistem sosial masyarakat Lombok yang bergantung pada tokoh agama mereka yaitu Tuan Guru.

Hal ini yang melatarbelakangi Salman Faris berani membangun diskursus melalui fiksi yang berjudul Tuan Guru. Sebab, fakta sosial yang terjadi berbeda dengan konstruksi berpikir masyarakat dengan Tuan Guru. Akibatnya, mereka tidak pernah tahu ketimpangan yang terjadi. Hal ini tampak dalam kutipan di bawah ini.

Papuk Odah tidak pernah sholat. Haram bagi mayatnya naik ke masjid. Kemudian disholatkan di dalamnya. Jika hidup saja ia tidak pernah naik ke masjid. Apalagi matinya. Itulah satu sangsi bagi mereka yang tidak mengikuti kelaziman di tengah masyarakatnya. Dikuburkan 
dengan cara tidak lazim (TG:425).

Diskursus tersebut memperlihatkan kebencian Salman Faris terhadap Tuan Guru. Sebab dalam kutipan tersebut, Salman Faris seperti ingin menunjukkan keaslian Tuan Guru dengan membongkar sisi lain dari Tuan Guru. Sebagai konsekuensinya, Salman Faris membangun diskursus secara berlebihan dalam mengonstruksikan Tuan Guru di dalam cerita novel.

Sejalan pendapat Foucault yang mengatakan bahwa subjektivitas sering dipandang, sebagai dampak atau efek dari wacana karena subjektivits dibentuk lewat posisi-posisi subjek yang "diwajibkan" oleh wacana untuk kita ambil (Barker, 2014:281-282). Seperti konsep Foucault tentang subjetivitas tersebut, Salman Faris di sini terlihat sebagai korban dari diskursus Tuan Guru sehingga membentuknya mengonstruksikan sikap dan tindakan Tuan Guru di tengah masyarakat Lombok. Kemudian, hal ini menjadi motivasi dari tindakan Salman Faris membangun diskursus tentang Tuan Guru meski berlebihan cara membangun diskursus di dalam cerita novel. Foucault juga mengatakan bahwa "kuasa tidak menindas, tetapi produktif. Kekuasan dia tidak berfungsi melalui hukuman dan memenjarakan tubuh, tetapi malah menambah kegunaannya dan memaksimalkan kekuatannya. Kuasa bersifat membatasi, tetapi juga membebaskan (Faucault dalam Alimi, 200424) Realitas kehidupan Salman Faris merupakan rangkaian peristiwa dari masa ke masa. Konstruksi nalar kritis yang terbentuk oleh lingkungan menjadi alasan kuat Salman Faris menulis novel Tuan Guru. Sebab, Salman Faris pernah menjadi santri Tuan Guru. Akibatnya, dia juga masuk dalam jamaah yang tunduk pada fatwa-fatwa Tuan Guru yang senantiasa dibenarkan dan menjalankan semua fatwa tersebut. Kuasa yang dimiliki Salman Faris setelah menempuh pendidikan di Jawa membebaskannya dari fatwa-fatwa Tuan Guru yang mengajak untuk terus ibadah. Sebab, dengan subjektivitasnya, Salman Faris berani membangun diskursus memalui pengetahuannya yang membentuk kebenaran melalui tulisan novelnya. Sejalan sebagaimana pendapat Foucault (dalam Lubis 2014a:76) mengemukakan bahwa adanya relasi yang signifikan kuasapengetahuan-kebenaran. Kuasa didapat dari pengetahuan dan dipraktikkan menggunakan wacana melalui bahasa. Dalam wacana itu, kebenaran dikonstruksi. Pada akhirnya, kebenaran adalah kekuasaan itu sendiri.

Kuasa menulis novel dengan pengetahuan yang sudah memahami ruang lingkup pergerakan Tuan Guru membentuk Salman Faris melahirkan kebenaran-kebenaran yang dia buat. Sebab, melalui novel ini, Salman Faris berjuang keras membongkar ketimpangan yang dibentuk Tuan Guru melalui diskursus pengetahuannya. Akan tetapi, kebenaran yang dibentuk oleh Salman Farisbukan kebenaran mutlak yang harus diikuti oleh pembaca 
karena tidak semua yang membaca novel Salman Faris akan menerima kebenaran yang ia bentuk.

\section{Dari Pimpinan Agama Menjadi Penguasa Politis}

Citra pengetahuan agama yang luas menjadi modal bagi setiap Tuan Guru yang di Lombok. Hal ini membentuknya menjadi penguasa politis. Politis di balik fatwa-fatwa yang menuntut masyarakat untuk menjalani. Sebab, setiap fatwa yang keluar dari Tuan Guru merupakan hasil akhir dari setiap kegelisahan masyarakat Lombok untuk mencari kebenaran tersebut. Kebenaran agama mutlak diyakini masyarakat Lombok. Sebab, hal ini terlihat dari penduduk yang mayoritas beragama Islam, yang membentuk mereka percaya bahwa kebenaran agama yang utama yang harus mereka ikuti.

Pada realitasnya, kebenaran yang menjadi titik acuan masyarakat Lombok adalah kebenaran yang difatwakan oleh Tuan Guru. Sebab, masyarakat Lombok tidak bisa keluar dari citra Tuan Guru yang diwacanakan memiliki pengetahuan agama yang luas. Hal ini sebagai akibat pengaruh ilmu Tuan Guru yang tuntut ke Mekah.

Siklus mengkonstruksi masyarakat untuk berani memilih. Pilihan untuk dijadikan panutan dalam hidup, karena Tuan Guru dipercaya bahwa semua hal yang baik ada di dalam Tuan Guru. Sebuah konstruksi berpikir yang membentuknya menjadi budak. Sebab, wacana Mekah-lah yang membentuk nalar mereka. Tuan Guru di Lombok merupakan orang yang dipilih menjadi pemimpin agama. Pemimpin agama diberikan hak dan wewenang untuk menyelesaikan permasalahanpermasalahan jamaahnya. Hak dan wewenang ini pula yang membuat kuasa Tuan Guru untuk membangun wacana berupa fatwa yang dipercaya kebenaran oleh para jamaahnya. Sejalan dengan teori Foucault (1997:30) yang mengatakan bahwa relasi pengetahuan dengan kuasa yang saling memperkembangkan. Tidak ada praktik pelaksanaan kuasa yang tidak memunculkan pengetahuan, dan tidak ada pengetahuan yang di dalamnya tidak mengandung relasi kuasa.

Relasi pengetahuan dengan kuasa membentuk konstruksi berpikir Tuan Guru untuk melakukan sesuatu yang akan menguntungkan bagi dirinya. Sebab, relasi pengetahuan dan kekuasaan ini akan membentuk seseorang untuk berkuasa.Untuk mendapatkan kekuasaan itu, Tuan Guru harus memahami pola pikir masyarakat dan sistem sosial masyarakat Lombok. Sebab, Tuan Guru ingin berkuasa di tengah masyarakat Lombok. Tuan Guru terlebih dahulu memahami konstruksi masyarakat. Dengan begitu, Tuan Guru dengan mudah membangun wacana di tengah masyarakat Lombok. Wacana tersebut merupakan bagian dari politik Tuan Guru untuk berkuasa di masyarakat Lombok. Sebab, Tuan Guru berhasil membangun wacana dan membentuk masyarakat Lombok untuk 
tunduk. Melalui pengetahuan Tuan Guru, hal ini letak keberhasilan politik Tuan Guru untuk berkuasa. Hal ini dapat dilihat dalam kutipan di bawah ini:

: Jadi, biar taat saya jalankan syari'at, terlebih dahulu saya sampaikan salam dari tuan guru. Ayahku tersenyum. Wajahnya memancarkan aura yang lain. Mengalahkan aura pagi matahari. Ibu datang membawa dua gelas air minum (TG:90).

Kutipan tersebut merupakan politisasi Tuan Guru ke jamaahnya. Dia menyuruh jamaah yang dia percaya untuk keliling ke jamaah yang lain. Tujuannya adalah untuk meminta sumbangankepengajiannya.PolitikTuan Guru dilakukan dengan membangun wacana tentang pengetahuan agama. Hal ini agar jamaahnya berlomba-lomba mendapatkan keberkahan dari ilmu yang dia miliki. Keberkahan ini akan dikejar oleh jamaah Tuan Guru. Sebagai akibatnya, mereka rela menyumbang dengan uang banyak agar mendapatkan doa dari Tuan Guru. Doa Tuan Guru diyakini lebih makbul dari doa-doa orang biasa.

Cermin keberhasilan politisasi Tuan Guru dengan citra kemampuan agama yang luas yang membentuk masyarakat menjadi patuh terhadap Tuan Guru. Kepatuhan membentuk mereka harus mengikuti setiap fatwa Tuan Guru. Sebab, masyarakat tidak akan pernah berani membantah orang yang mereka anggap paham dalam hal agama. Sejalandenganapa yang diungkapkanolehFaucault (dalam Hardiyanta, 1997:76) bahwa "disiplin merupakan mekanisme "kontrol" yang teliti atas tubuh". Melalui disiplin, tubuh dilatih hingga menjadi tubuh yang terampil. Namun, hal ini juga terus-menerus diuji dan dikoreksi sehingga keterampilan, kecekatan, dan kesiapsediaan ini akhirnya menjadi mekanisme yang dengan begitu saja bekerja di dalam tubuh itu sendiri. Disiplin sekaligus meningkatkan keterampilan, kekuatan, dan daya guna tubuh. Akan tetapi, hal ini juga menguasai dan menempatkan tubuh ke dalam relasi tunduk dan berguna.

Tubuh yang patuh merupakan entitas keberhasilan Tuan Guru membangun politik kekuasaannya di tengah masyarakat Lombok. Sebba, setiap fatwa Tuan Guru merupakan rangkaian kuasa ke kuasa yang lain yang harus dia capai dengan tujuan berkuasa. Realitas sosial yang terbentuk dari setiap fatwa dengan tujuan kekuasaan merupakan politik Tuan Guru yang sudah terencana agar bisa menguasai masyarakat Lombok pada umumnya.

Seperti yang diungkapkan Salim (wawancara, Januari 2016) mengatakan bahwa dia menyekolahkan anaknya ke pondok pesantren karena menjalankan fatwa dari Tuan Guru. Fatwa yang dianggap benar. Sebab, setiap fatwa yang dikeluarkan Tuan Guru merupakan kebenaran tunggal yang mereka harus ikuti. Salim juga mengungkapkan bahwa tidak mungkin Tuan Guru mengajak 
mereka ke jalan yang buruk. Sebab, Tuan Guru merupakan tokoh panutan yang selalu diidolakan dalam kelompok masyarakat. Politik Tuan Guru muncul dalam keadaan ini. Dia membangun diskursus dengan cara kelebihan dan kekurangan sekolah agama dengan sekolah umum yang bertujuan agar anak-anak jamaahnya untuk sekolah ke pondok pesantren yang dia pemimpin.

Proses perjalanan kekuasaan Tuan Guru tidak terlalu banyak rintangan. Memiliki citra lulusan Mekah menjadi modal Tuan Guru. Sebab, sepulangnya dariMekah, tugasTuan Gurumeyakinkan masyarakatbahwa dia merupakan orang yang memiliki pengetahuan agama yang luas. Ketika masyarakat percaya terhadap ke ilmuan Tuan Guru, Tuan Guru tersebut dipilih oleh kelompok masyarakat untuk menjadi pemimpin agama mereka. Keputusan masyarakat memiliki dasar yang kuat dan diketahui Tuan Guru. Dia merupakan ulama yang dipercaya sebagai panutan mereka. Konstruksi masyarakat ini terbentuk oleh pengetahuan agama yang dimiliki Tuan Guru sehingga mereka menjadi tunduk dan patuh. Cerminkeberhasilan Tuan Guru sebagai penguasa di tengah jamaahnya juga terlihat dari tunduk dan patuhnya Salim yang menyekolahkan anaknya ke pondok pesantren bukan atas dasar keinginanya, tetapi karena petunjuk dari Tuan Guru. Petunjuk ini dianggap tepat untuk masa depan anaknya.

Seperti yang diungkapkan Faucault dalamDisciplineandPunishbahwa"tubuh juga terlibat langsung dalam ranah politik, relasi kekuasaan, memunculkan cengkeraman langsung terhadapnya, relasi kekuasaan menyemainya, melatihnya, menyiksanya, menandainya, memaksanya untuk melakukan banyak tugas". Selain itu, investasi politik tubuh ini terikat sejalan dengan relasirelasi timbal balik yang kompleks dan dikaitkan dengan berbagai relasi kekuasaan dan dominasi. Menjadi tubuh yang bermanfaat bila produktif sekaligus patuh dan menjadi budak (Faucault dalam Lubis, 2014:82). Keberhasilan Tuan Guru membangun wacana membentuknya menjadi penguasa di tengah masyarakat Lombok. Patuh dan tunduk memberikan jalan bagi Tuan Guru untuk membentuk norma-norma yang berlandasan agama. Sebagai akibatnya, Tuan Guru dengan mudah mengajak jamaahnya ke arah yang sudah direncana oleh Tuan Guru. Sebab, hal ini terlihat jelas dalam dampak setiap fatwa Tuan Guru yang berada di tengah jamaahnya. Hal ini mengikuti dan tidak pernah dibantah oleh jamaahnya. Proses realitas dari setiap tindakan Tuan Guru di tengah jamaahnya menjadi sebuah proses yang dahulunya hanya sebagai orang biasa kemudian sepulangnya dari Mekah masyarakat langsung mendeklarasikan Tuan Guru sebagai pemimpin agama. Setelah dia menjadi pemimpin agama, Tuan Guru menjadi kiblat jamaahnya untuk dijadikan sebagai tempat mencari kebenaran. Tuan Guru tempat semua harapan bagi jamaah yang mencari 
kebenaran agar bisa menjalankan hidup sesuai ajaran agama yang dia yakini. Akibatnya, dia tidak keliru dalam bersosialisai dalam masyarakat dan beragama.

Menjadi seorang penguasa politisi merupakan sebuah keuntungan besar bagi seorang Tuan Guru. Dengan kepercayaan masyarakat, Tuan Guru dengan mudah mengajak jamaahnya ke tempatyang sudah dia rencanakan. Tuan Guru akan terus berkuasa di tengah satu kelompok tersebut. Masyarakat yang sudah patuh akan selalu menganggap semua fatwa yang keluar dari Tuan Guru merupakan fatwa yang benar dan harus mereka jalani. Hal inilah konstruksi jamaah Tuan Guru. Sebab, masyarakat menganggap tidak mungkin tokoh agama yang mereka hormati akan melakukan penyimpangan di luar batas pengetahuan agama yang dia miliki.Pada realitasnya, pengetahuan itulah yang membentuk Tuan Guru melalui kebenaran-kebenaran yang akan membuatnya menjadi penguasa di tengah jamaahnya. Hal ini terlihat dari kutipan di bawah ini:

Beribu-ribu orang.

Ah! tidak terbilang banyaknya.

Semua orang. Setiap santri mengejar satu tujuan itu, jadilah tuan guru anaku. Bukan karena aku tidak mampu mengejar tujuan itu, yang membuat aku tidak bisa menjadi tuan guru. Tetapi karena aku tidak mau. Sekali lagi. Tidak mau. Merah wajah ibu. Ia merasa telah didurhakai(TG:457).

Diskursus tersebut merupakan cara Salman Faris menggambarkan mimpi santri untuk masa depannya. Salman Faris menggambarkan orang tuanya menyuruh agar dia menjadi Tuan Guru. Salman Faris menggambarkan konstruksi berpikir jamaah Tuan Guru yang sudah dikuasai untuk memiliki keinginan lebih dari sekedar menjalankan setiap fatwa Tuan Guru. Sebab, jamaahnya ingin melihat anakanak mereka bisa menjadi seperti Tuan Guru juga. Hal ini adalah sebuah cita-cita yang sudah terkonstruksi oleh doktrin-doktrin di setiap pengajian Tuan Guru. Hal ini adalah tujuan politis Tuan Guru yang tampak menjadi nyata dalam melihat para jamaahnya yang mau menyekolahkan anak-anak mereka ke pondok pesantren yang Tuan Guru pimpin. Politik Tuan Guru menjadi berhasil karena dukungan jamaahnya yang mau mengikuti apa yang diperintah Tuan Guru. Sebab, hal ini tidak akan bisa berjalan menjadi suatu lembaga seperti pondok pesantren jika tidak memiliki santri.

Moesa (2007:93-94) mengatakan bahwa pesantren adalah institusi pendidikan yang di bawah pimpinan seseorang atau beberapa kiai dan dibantu oleh sejumlah santri senior serta beberapa anggota keluarganya. Pesantren menjadi bagian sangat penting bagi kehidupan kiai sebab dia merupakan tempat bagi sang kiai untuk mengembangkan dan melestarikan ajaran, tradisi, dan pengaruh 
dimasyarakat. Salah satu unsur berjalannya roda pondok pesantren yaitu santri. Santri adalah menjadi tulang punggung untuk berjalannya pondok pesantren Tuan Guru karena kalau tidak santri tidak akan mungkin bisa berjalan pondok pesantren tersebut.

Pondok pesantren dalam teori Foucault tentang power dipahami sebagai institusi-institusi yang didirikan oleh penguasa sebagai sarana untuk mendisiplinkan dan mensosialisasikan norma-norma kepada individu-individu (Lubis, 2014:80). Dalam bukunya berjudul The History of Sexuality (1978), Foucault menguraikan bahwa "Biopower adalah satu bentuk kekuasaan yang berfokus pada bagaimana mengatur kehidupan manusia pada tingkat populasi massa". Pada biopower, institusi melakukan sesuatu yang disebut "power/knowledge".Hal itu dilakukan dengan cara pelatihan dan pendidikan bagi individu. Hal ini meningkatkan dan mengatur kehidupan manusia secara umum (Foucault dalam Lubis, 2014:80).

Sesuatu yang disampaikan Foucault (dalam Lubis 2014:80) tersebut sesuai dengan realitas yang terjadi pada masyarakat Lombok. Kekuasaan yang terbentuk dari pengetahuan agama yang melahirkan power bagi Tuan Guru untuk membangun diskursus guna menguasai dalam suatu kelompok masyarakat. Perubahan status sosial Tuan Guru dari pemimpin agama menjadi penguasa politis tidak disadari oleh masyarakat.
Sebab, hal ini terbentuk menjadi jamaah yang patuh dan membuat mereka tidak sadar. Setiap fatwa atau kebijakan dari Tuan Guru selalu menguntungkan bagi Tuan Guru sebab kebijakan atau fatwa tersebut tidak pernah lepas dari kebenaran agama yang Tuan Guru pahami. Kebenaran yang tidak dipertanyakan kembali oleh masyarakat. Akibatnya, doktrindoktrin mengharuskan mereka untuk berlomba-lomba mengejar pahala yang di dalamnya adalah ajaran-ajaran untuk terus beribadah.

Hal ini berbanding terbalik dengan kenyataan yang terjadi di tengah masyarakat. Pada faktanya, keberhasilan Tuan Guru sebagai penguasa politis terlihat dari beberapa anak Tuan Guru yang disekolahkan di luar pondok pesantren yang dipimpin oleh Tuan Guru. Banyak anak Tuan Guru disekolahkan di luar pulau Lombok, ada yang di Jawa sampai ke luar negeri. Hal ini tampak dalam kutipan di bawah ini:

Banyak sekali, anak-anak tuan guru disekolahkan di Jawa. Di perguruan tinggi negeri ternama. Bahkan di luar negeri. Mengambil kuliah yang memiliki masa depan. Sedangkan anak-anak jemaahnya dibiarkan. Dipaksakan terkantung-kantung pada garis nasibnya, di pondok pesantren. Di sekolah-sekolah pelosok desa. Sekolah tanpa informasi (TG:439).

Menjadi penguasa politis, Tuan Guru dengan mudah mengatur masa 
depan anak-anaknya dan anakanak jamaahnya. Kutipan tersebut menjelaskan bagaimana Tuan Guru bukan hanya sebagai pemimpin agama di tengah jamaahnya, tetapi dia juga sebagai pemegang kebijakan untuk jamaahnya yang membentuknya sebagai penguasa politis.

Bentuk entitas dari eksistensi Tuan Guru di tengah masyarakat hanya ingin menjadi penguasa. Penguasa bisa mengatur sistem sosial masyarakatnya. Akibatnya, Tuan Guru dengan mudah mengajak jamaahnya ke arah yang sudah direncanakan. Maka, Tuan Guru menjadi penguasa di tengah jamaahnya yang berlomba-lomba untuk beribadah. Sementara itu, disisi lain, anak dan keluarganya terus direncanakan sebagai penerus kekuasaan guna menggantikan kekuasaannya.

Kuasa pengetahuan dari Salman Faris mengonstruksinya dengan cara berani membangun diskursus yang dia tulis di dalam novel. Oleh karena itu, hal ini terlihat ketika Salman Faris menceritakan secara detail proses siklus Tuan Guru yang dahulu sampai sekarang. Kuasa Salman Faris memang tidak bisa ditolak. Melalui pengalaman bermasyarakat dan memahami pola pikir masyarakat dan Tuan Guru, hal ini membuatnya menjadi berani mengangkat kepermukaan sisi lain dari Tuan Guru, seperti yang dia tulis dalam novel tersebut.

Luapan emosi yang tertumpah memperlihatkan kekecewaan Salman Faris terhadap Tuan Guru. Hal ini terlihat dalam beberapa kutipan dalam novelnya. Salman Faris berani membongkar keburukan Tuan Guru yang dianggap wajar oleh masyarakat. Berikut adalah kutipannya:
Namun, akibat dari semua kebijakan yang ia telurkan dengan sangat terselubung ke tengah masyarakat, yang ratusan tahun terasa dan susah menghilangkan jejak, itulah yang membuatku tidak bisa memaafkannya.
Sehingga, seandainya seperti dia orang terbaik yang pernah dilahirkan pulauku. Demi tuhan, dan demi semua penciptaannya, aku malu pernah dilahirkan oleh pulau tempat seribu kubah masjid bertarung lewat corong klaim kebenaran agama itu (TG:640).

Kutipan tersebut merupakan luapan kekecewaan Salman Faris terhadap Tuan Guru dan pulau kelahirannya. Sebab, Salman Faris menilai masyarakat Lombok merupakan masyarakat yang bergantung hidup pada tokoh agamanya. Akibatnya, kebenaran agama menjadi kiblat utama dalam hidup mereka. Hal ini yang dikritisi oleh Salman Faris dalam melihat ketimpangan sosial masyarakat Lombok yang sengaja dibentuk oleh Tuan Guru.

Kekecewaan Salman Faris juga menunjukkan bahwa dia juga menjadi salah satu korban dari diskursus Tuan Guru. Hal terlihat dalam luapan emosinya. Salman Faris mengklaim keluarganya masuk menjadi jamaah 
Tuan Guru, terlebih lagi Salman Faris juga pernah menjadi santri Tuan Guru.

Subjektivitas Salman Faris dalam melihat ketimpangan ini terlihat dalam hasrat ingin membongkar sisi lain Tuan Guru. Selain itu, dia menunjukkan kepada semua orang bahwa Tuan Guru adalah orang yang ingin kekuasaan. Kekuasaan itu di bangun dari pengetahuan agama yang dia miliki. Akibatnya, hal ini membentuk masyarakat menjadi tunduk terhadap Tuan Guru.

Hasrat ingin membongkar sisi lain Tuan Guru dilakukan dengan mengangkat melalui tulisan yang berupa novel. Hal ini semakin memperkuat keinginan Salman Faris untuk menunjukkan dirinya. Hasrat ingin terkenal melalui diskursus yang dia bangun melalui novel merupakan salah satu tujuannya. Novel Tuan Guru ini menjadikan nama Salman Faris terkenal di Lombok, karena kontroversi dalam ceritanya.

Dari analisis ini dapat disimpulkan bahwa diskursus Tuan Guru di wacanakan oleh pengarang novel Salman Faris. Kuasa pengetahuan pengarang mewacanakan diskursus Tuan Guru. Pengetahuan tentang Tuan Guru mendatangkan power knowledge (kuasa pengetahuan) bagi setiap individu di masyarakat Lombok. Baudrillarrd mengatakan (2006: 1-78) bahwa diskursus Foucault adalah cerminan dari kekuasaan yang digambarkannya. Hal ini adalah letak kekuasaan dan seduksinya (rangsangannya), sama sekali di dalam "indeks kebenaran" dalam diskursus tersebut. Hal ini berfungsi sebagai leitmotif: prosedur-prosedur kebenaran tidak penting. Sebab, diskursus Foucault lebih benar dari diskursus-diskursus lain. Baudrillard menitikberatkan ungkapan Foucault tentang hasrat. Foucault tidak mengetahui ada simulasi dibalik dikursus pengetahuan yang melahirkan kekuasaan yang kemudian menjadi kebenaran. Hasrat merupakan alam bawah sadar manusia. Hasrat inilah yang menjadi simulasi. Salman Faris sebagai pengarang novel Tuan Guru melakukan representasi melalui novel ini hanya simulasi. Sebab, hasrat Salman Faris berani membongkar diskursus Tuan Guru. Kemudian dia membangun diskursus baru dengan menulis novel.

\section{SIMPULAN}

Salman Faris menampilkan sisi lain dari Tuan Guru yang tidak bisa dianalisis oleh masyarakat biasa. Salman Faris berani membongkar pengaruh karisma Tuan Guru di tengah masyarakat Lombok dengan cara membangun diskursus baru melalui karyanya fiksinya yang berjudul Tuan Guru. Akan tetapi, dalam representasinya, Salman Faris disini juga sudah paham kondisi sosial masyarakat Lombok dan Tuan Guru. Ketika Salman Faris berani membangun diskursus melalui tulisannya, dia tahu bahwa novel tersebutakan menjadi novel kontroversi dalam kalangan pembaca. Letak hasrat 
Salman Faris berada dalam kondisi ini, yakni hasrat ingin menjadi terkenal. Akibatnya, melalui novel ini, Salman Faris menjadi pengarang kontroversi karena dia berani membongkar sisi lain dari Tuan Guru. Konsep Baudrillard tentang hasrat yang muncul tersebut hanya simulasi sehingga Salam Faris membangun diskursus Tuan Guru yang membuatnya menjadi orang yang berpengaruh dan terkenal di Lombok sampai sekarang.

Dengan kata lain, hal ini dapat dikatakan bahwa novel Tuan Guru mengunggulkan Salman Faris sebagai pengarang sebab telah berani membongkar tokoh agama yang paling berpengaruh di Lombok. Wacana yang dibangun secara halus membuat Tuan Guru menjadi kambing hitam dalam kompleksitas permasalahan dalam kehidupan sosial masyarakat Lombok. Akan tetapi, Foucault mengatakan bahwa kekuasaan berada dimanamana, selama ada relasi antara, bahasapengetahuan-kebenaran. Setiap orang berhak membangun diskursus. Melalui diskursus yang ada, novel ini menjadi kontroversi.

\section{DAFTAR PUSTAKA}

Akbar, et al. (2013). Kajian sosiologi sastra dan nilai pendidikan dalam novel "Tuan Guru" karya salman faris. dalam Jurnal Pendidikan Bahasa dan Sastra. Vol 1, No 1, Hal 54-68.

Fayyadl, M.A. (2012). Derrida. Yogyakarta: LKiS.

Alimi, M.Y. (tanpa tahun). Dekonstruksi seksualitas poskolonial, dari wacana bangsa hingga wacana agama. Yogyakarta: LKSI.

Aziz, M.I. (2001). Esai-Esai Jean Budrillard: galaksi simulacra. Yogyakarta: LKSI.

Barker, C. (2013), Cultural studis. teori dan praktik. Yogyakarta: Kreasi wacana.

(2014). Kamus kajian budaya. Yogyakarta: PT Kanisius.

Baudrillard, J. (2015). Lupakan postmodernisme. Bantul. Kreasi Wacana.

Cavallaro, D. (2001). Critical and Cultural theory. London: The Athlone Press.

Fahrurrozi. (2010). Tuan guru antara identitas normatif dengan realitas sosial pada masyarakat lombok. dalam Jurnal Penelitian Keislaman. Vol 7, No 1, Hal 221-250. Desember 2010.

Fashri, F. (2007). Penyingkapan kuasa simbol. Yogyakarta: Juxtapose.

Foucault. (1997). Sejarah seksual seks dan kekuasaan. Jakarta: PT Gramedia Pustaka Utama.

Hall, Stuart et al (ed.). (2011). Budaya, media, bahasa: teks utama 
pencanang cultural studies 19721979. Terj. Yogyakarta: Jalasutra.

Hardiyatna, P.S. (1997). Michael foucault: disiplin tubuh-bengkel individu modern. Yogyakarta: LKSI.

Lubis, A.Y. (2014). Postmodernisme, teori dan metode. Jakarta: PT Raja Hrafindo Persada: Rajawali Pers.

___ (2014). Teori dan metodelogi ilmu pengetahuan sosial budaya kontemporer. Jakarta: PT Raja Hrafindo Persada: Rajawali pers.

Moesa, A.M. (2007). Nasionalisme kiai: konstruksi sosial berbasis agama. Yogyakarta: LKSI.

Salamah, U. (2015). Perspektif teori postmodern terhadap problema sosial politik kontemporer. Malang. Media Nusa Creative.

Sardiman, A.M. (2014). Interaksi \& motivasi belajar mengajar: Jakarta: Rajawali Pers.

Suryawan, I.N. (2010). Geneologi kekerasan dan pergolakan subaltern: bara di bali utara. Jakarta: Predana. 